\title{
Cemaran Timbal (Pb) dan Arsen (As) pada Susu Sapi Perah yang Diberi Pakan Limbah Organik Pasar di Peternakan Sapi Perah Kebon Pedes Bogor
}

\section{Heavy Metals Pb and As In Fresh Milk from Cows fed by in Different Roughages Kebon Pedes Bogor Dairy Cattle}

\author{
Salundik $^{1}$, Suryahadi ${ }^{2}$, S.S. Mansjoer ${ }^{1}$, D. Sopandie ${ }^{3}$ dan W. Ridwan ${ }^{4}$ \\ ${ }^{1}$ Departemen Ilmu Produksi dan Teknologi Peternakan Institut Pertanian Bogor \\ ${ }^{2}$ Departemen Ilmu Nutrisi dan Teknologi Pakan Institut Pertanian Bogor \\ ${ }^{3}$ Departemen Ilmu Agronomi Institut Pertanian Bogor \\ ${ }^{4}$ Program Studi PSL Pascasarjana IPB \\ e-mail: ndikipb@yahoo.co.id
}

(Diterima: 15 Mei 2011; Disetujui: 11 November 2011)

\begin{abstract}
The aims of livestock development is to increase both quality and quantity production, in the same time, ensure the safety of the product. The consumers need to concern about food safety of livestock products because it is related to human's health. The research was conducted to determine food safety of dairy condition by detecting heavy metal on fresh milk produce by Kebon Pedes Dairy Farm. This research was utilited survey method and cases study and the result analyzed descriptively. The parameters measured are heavy metal Plumbum $(\mathrm{Pb})$ and Arsenic (As) contents by using Atomic Absorption Spectrophotometer $(A A S)$ machine. The result of the study indicated that $P b$ and As undetected in fresh milk. That's value lower than standar maxsimum limit according SNI 01-3141-1998 were 0,3 ppm and 0,5 ppm.
\end{abstract}

Keywords: fresh milk, $\mathrm{Pb}$, As

\section{PENDAHULUAN}

Penyediaan pakan dalam usaha peternakan sapi perah merupakan biaya produksi terbesar yang dihadapi peternak, sehingga pakan menjadi salah satu permasalahan utama. Hijauan makanan ternak (HMT) sebagai pakan utama semakin sulit diperoleh akhir-akhir ini akibat berkurangnya lahan untuk pengembangan produksi hijauan. Beberapa penyebabnya adalah keperluan pemukiman dan alih fungsi lahan. Pakan alternatif untuk mengganti sebagian atau seluruh hijauan makanan ternak perlu dicari sebagai sumber pakan baru untuk kelangsungan usaha peternakan khususnya sapi perah.

Alternatif sumber pakan pengganti HMT yang dapat dijadikan sumber pakan baru untuk mengatasi masalah penyediaan pakan yaitu dengan memanfaatkan sampah sayuran pasar yang ada. Pemanfaatan sampah pasar selain dapat membantu kelangkan HMT, turut berperan dalam mengurangi timbunan sampah. Selain menguntungkan dari segi ekonomis bagi peternak, cara ini pun dapat membantu mengatasi pencemaran lingkungan di daerah perkotaan, namun sampah ini harus dibersihkan dan dipilih terlebih dahulu sebelum dikonsumsi ternak. Salah satu sampah sayuran pasar yang dapat menggantikan penggunaan hijauan pakan ternak adalah klobot jagung. Klobot jagung atau kulit jagung merupakan hasil sampingan dari pemanenan jagung. Kirakira $50 \%$ dari berat total tanaman jagung adalah limbah yang ditinggalkan setelah pemanenan. Persentase masing-masing limbah antara lain : 50\% tangkai, $20 \%$ daun, $20 \%$ tongkol jagung dan 10\% klobot jagung (Samples dan Mc. Cutcheon, 2003). Jika dilihat dari ketersediaan dan kualitas nutrisinya, klobot jagung masih lebih baik dibandingkan dengan rumput lapang. Namun, dikhawatirkan penggunaan sampah pasar berupa klobot jagung sebagai bahan pakan ternak sapi perah akan mencemari air susu sapi, mengingat sampah tersebut kemungkinan mengandung cemaran logam berat seperti $\mathrm{Pb}$ dan As. Mengingat susu umumnya dikon- 
sumsi oleh hamper semua golongan umur anak-anak hingga orang dewasa (Caggiano et al., 2005 dan Zheng et al., 2007). Logam berat adalah unsur yang mempunyai gaya berat spesifik logam lebih dari 5 dan merupakan unsur dengan jumlah atom 22-34 dan 40-52 serta latanida dan aktinida. Logam berat diketahui dapat mengumpul di dalam tubuh dan tetap tinggal dalam tubuh untuk jangka waktu lama sebagai racun yang terakumulasi (Saeni, 1997).

Pencemaran logam ini dapat berasal dari sistem pertanian intensifikasi yang menggunakan pestisida didalamnya dan lokasi penanaman dekat dengan jalan raya. Pencemaran setelah pemanenan dapat terjadi dari bahan aditif bensin kendaraan bermotor, dan sampah yang bercampur dengan peralatan elektronik, plastik, koran, kertas serta debu sapuan jalanan.

Penelitian ini bertujuan untuk menganalisis cemaran logam berat $(\mathrm{Pb}$ dan $\mathrm{As})$ pada susu asal sapi perah yang diberi pakan klobot jagung sebagai pengganti hijauan.

\section{METODE}

Penelitian ini dilakukan di Peternakan Sapi Perah Kebon Pedes, Bagian Ilmu Produksi Ternak Perah Departemen Ilmu Produksi dan Teknologi Peternakan, dan Bagian Ilmu Nutrisi Ternak Perah Departemen Ilmu Nutrisi dan Makanan Ternak, Fakultas Peternakan, Institut Pertanian Bogor. Sapi perah yang digunakan sebanyak 24 ekor dari peternakan yang menggunakan hijauan rumput lapangan, 18 ekor dari peternakan yang menggunakan hijauan berupa klobot jagung, dan 46 ekor dari peternakan yang menggunakan hijauan campuran antara rumput lapang $40 \%$ dan klobot jagung $60 \%$. Peubah yang diamati dalam penelitian ini adalah kandungan logam berat timbal dan arsenik. Data hasil penelitian diperoleh melalui metode survey dan analisa laboratorium, kemudian data yang diperoleh dianalisis menggunakan analisis statistik deskriptif.

\section{Prosedur}

Bahan utama yang digunakan dalam penelitian ini adalah sampel pakan ternak, air minum ternak dan susu segar. Sampel pakan ternak berupa rumput lapangan, klobot jagung, konsentrat, ampas tahu, dan ampas tempe. Sampel susu yang digunakan merupakan sampel susu kandang yang diambil dari 9 lokasi peternakan di Kelurahan Kebon Pedes, antara lain: 3 sampel dari peternakan yang menggunakan pakan hijauan rumput lapangan, 3 sampel dari peternakan yang menggunakan pakan hijauan klobot jagung dan 3 sampel dari peternakan yang menggunakan pakan hijauan campuran antara rumput lapangan dan klobot jagung.

\section{Pengambilan Sampel untuk Pengukuran Kadar Air, Residu Logam Berat Pb dan As}

Pengambilan sampel dilakukan di Peternakan Sapi Perah Kebon Pedes. Sampel yang diambil terdiri atas sampel pakan ternak, air minum ternak dan susu segar. Sampel pakan terdiri atas rumput lapangan, klobot jagung, konsentrat, ampas tahu, dan ampas tempe. Sampel diambil dari sembilan lokasi peternakan yang dibedakan berdasarkan jenis pakan hijauan yang diberikan, yaitu rumput lapangan, klobot jagung dan campuran antara rumput lapangan dan klobot jagung. Masingmasing sampel tersebut diambil dari tiga lokasi peternakan dengan jenis pakan hijauan yang berbeda. Sampel pakan ternak dan susu segar diambil pada pagi dan sore hari.

\section{Analisis Logam Berat $\mathrm{Pb}$ dan As pada Pakan Ternak dan Susu Segar dengan Metode Pengabuan Basah}

Analisis logam berat $\mathrm{Pb}$ dan As dilakukan dengan metode pengabuan basah, lalu dilanjutkan dengan analisis sampel hasil pengabuan basah menggunakan spektofotometer serapan atom $(A A S)$ dengan panjang gelombang yang berbeda-beda untuk setiap jenis logam. Sebanyak \pm 1 gram sampel dimasukkan ke dalam tabung Erlenmeyer ukuran $125 \mathrm{ml}$ atau $100 \mathrm{ml}$, kemudian ditambahkan 5 $\mathrm{ml} \mathrm{HNO}_{3}$ dan diamkan pada suhu ruang di 
ruang asam. Sampel dipanaskan di atas hot plate dengan suhu rendah selama 4-6 jam masih dalam ruang asam, kemudian sampel ditutup dan dibiarkan semalam. Sebanyak 0,4 $\mathrm{ml} \mathrm{H}_{2} \mathrm{SO}_{4}$ ditambahkan kedalam sampel, lalu dipanaskan diatas hot plate sampai larutan berkurang (lebih pekat), biasanya \pm 1 jam. Sampel ditambah kembali dengan larutan campuran $\mathrm{HClO}_{4}$ dan $\mathrm{HNO}_{3}$ dengan perbandingan 2:1 sebanyak 2-3 tetes. Sampel masih tetap berada diatas hot plate hingga terjadi perubahan warna dari coklat menjadi kuning tua kemudian kuning muda. Pemanasan dilanjutkan selama 10-15 menit setelah terjadi perubahan warna. Sampel dipindahkan dari atas hot plate. Sebanyak $2 \mathrm{ml}$ aquades dan 0,6 $\mathrm{ml} \mathrm{HCl}$ ditambahkan pada sampel yang telah didinginkan terlebih dahulu. Sampel kembali dipanaskan selama \pm 15 menit agar larut dengan baik, kemudian dimasukkan kedalam labu takar $100 \mathrm{ml}$. Sampel yang mengandung endapan disaring dengan glass wool. Hasil pengabuan basah kemudian dianalisis menggunakan AAS untuk analisis berbagai mineral/ logam berat diantaranya logam $\mathrm{Pb}$ dan As.

\section{Cara Kerja Atomic Absorption Spectrophotometer (AAS).}

Analisis logam berat menggunakan AAS yaitu berdasarkan Hukum Lambert-Beert yang menyatakan bahwa banyaknya sinar yang diserap berbanding lurus dengan kadar zat. Persamaan garis antara konsentrasi logam berat dengan absorbansi adalah persamaan linier dengan koefisien arah positif: $y=a+b x$.
Penghitungan kadar logam berat dengan cara mensubtitusi nilai absorbansi larutan sampel ke dalam persamaan garis larutan standar. Cara kerja AAS yaitu berdasarkan penguapan larutan sampel, kemudian logam yang terkandung didalamnya diubah menjadi atom bebas. Atom tersebut mengabsorpsi radiasi dari sumber cahaya yang dipancarkan dari lampu katoda yang mengandung unsur yang telah ditentukan yaitu $\mathrm{Pb}$ dan As. Banyaknya penyerapan radiasi kemudian diukur pada panjang gelombang tertentu menurut jenis logam Pb dan As (Darmono, 1995).

\section{Kualitas dan Kuantitas Pakan}

Berdasarkan penggunaan pakan hijauan, peternak sapi perah di Kelurahan Kebon Pedes dibedakan dalam tiga kelompok, yaitu: (1) kelompok petenak yang menggunakan pakan hijauan rumput lapangan, (2) kelompok peternak yang menggunakan pakan hijauan klobot jagung, dan (3) kelompok peternak yang menggunakan pakan hijauan campuran antara rumput lapangan dan klobot jagung. Peternak sapi perah di Kelurahan Kebon Pedes selain menggunakan pakan hijauan juga menggunakan pakan penguat yang terdiri atas konsentrat, ampas tahu dan ampas tempe. Konsentrat yang digunakan diperoleh dari koperasi produksi susu yang berada di wilayah Kelurahan Kebon Pedes. Kualitas pakan hijauan dan pakan penguat yang diberikan oleh peternak sapi perah di Kelurahan Kebon Pedes dapat dilihat pada Tabel 1.

Tabel 1. Kandungan Zat Makanan dari Beberapa Bahan Pakan yang Digunakan Peternak di Kebon Pedes

\begin{tabular}{lccccccc}
\hline \multicolumn{1}{c}{ Bahan Pakan } & Bahan & \multicolumn{6}{c}{ Parameter (\% BK) } \\
\cline { 3 - 8 } & Kering $(\%)$ & Abu & Protein & Lemak & Serat Kasar & BET & TD \\
\cline { 3 - 8 } & & & & & & & \\
\hline Klobot Jagung & 27,91 & 2,97 & 4,34 & 0,68 & 25,98 & 66,03 & 65,7 \\
Rumput Lapangan & 21,74 & 7,43 & 6,61 & 1,52 & 37,15 & 47,29 & 56,2 \\
Konsentrat & 83,93 & 16,49 & 8,35 & 3,01 & 8,86 & 63,29 & 71,0 \\
Ampas Tahu & 17,00 & 2,33 & 20,42 & 12,83 & 24,23 & 50,19 & 74,9 \\
Ampas Tempe & 22,77 & 2,64 & 18,91 & 10,41 & 34,31 & 33,73 & 60,2 \\
\hline
\end{tabular}

Keterangan: Hasil Analisis Pusat Penelitian Sumberdaya Hayati dan Bioteknologi, (2008) 
Pakan sapi perah yang mempunyai kandungan bahan ekstak tanpa nitrogen (BETN) yang tinggi seperti klobot jagung dapat digunakan sebagai sumber energi terutama karbohidrat yang sangat dibutuhkan oleh sapi yang sedang laktasi untuk produksi susu. Pakan sapi perah yang mempunyai total digestible nutrient (TDN) yang tinggi akan lebih mudah dicerna sehingga kandungan nutrisi yang terkandung dalam bahan pakan tersebut tersebut dapat dimanfaatkan jauh lebih baik oleh sapi perah.

Kualitas konsentrat yang diberikan oleh peternak sapi perah di Kelurahan Kebon Pedes belum mencukupi untuk pencapai kemampuan produksi susu yang tinggi dan berkualitas. Menurut Siregar (1992) pakan sapi perah laktasi mengandung protein kasar $18 \%$ dan TDN $75 \%$ atau sekitar $4,75 \mathrm{M} \mathrm{kal} / \mathrm{kg}$ dari bahan kering. Biasanya peternak sapi perah di Kelurahan Kebon Pedes memenuhi kebutuhan protein untuk sapi perah dengan memberi pakan tambahan yang berasal dari limbah industri seperti ampas tahu dan ampas tempe.

Konsumsi bahan kering rata - rata masing - masing adalah 35,9 kg/ekor/hari pada kelompok petenak yang menggunakan pakan hijauan rumput lapangan; $37,8 \mathrm{~kg} /$ ekor/hari pada kelompok petenak yang menggunakan pakan hijauan klobot jagung; dan $33,0 \mathrm{~kg} /$ ekor/hari pada kelompok petenak yang menggunakan pakan hijauan rumput lapangan dan klobot jagung (campuran). Perimbangan konsumsi bahan kering rata-rata antara pakan hijauan dengan pakan penguat pada setiap kelompok peternak masingmasing adalah 42 : 58 pada kelompok petenak yang menggunakan pakan hijauan rumput lapangan; 44 : 66 pada kelompok petenak yang menggunakan pakan hijauan klobot jagung; dan 45 : 55 pada kelompok petenak yang menggunakan pakan campuran antara rumput lapangan dan klobot jagung.

\section{Logam Berat Timbal (Pb) dan Arsen (As) dalam Pakan}

Keberadaan logam $\mathrm{Pb}$ dan As dalam tubuh sapi yang utama berasal dari konsumsi pakan yang tercemar kedua logam tersebut. Banyaknya konsumsi logam berat sangat tergantung pada konsentrasi dan jumlah pakan yang dikonsumsi (Kinsara dan Farid. 2004) .

Ternak sapi yang menderita keracunan logam $\mathrm{Pb}$ dan As kebanyakan berasal dari rumput dan air minum yang tercemar. Keracunan logam $\mathrm{Pb}$ dan As pada ternak sapi biasanya berpengaruh terhadap produksi, disamping itu timbulnya residu logam $\mathrm{Pb}$ dan As dalam susu dapat menurunkan kualitas susu yang dihasilkan, karena sebagian logam $\mathrm{Pb}$ dan As yang masuk ke dalam tubuh sapi akan diekskresikan melalui susu.

Konsentrasi logam $\mathrm{Pb}$ dan As dalam pakan yang dikonsumsi oleh ternak sapi biasanya sangat bervariasi, sehingga keberadaan logam tersebut dalam tubuh sapi berbedabeda. Batas toleransi logam $\mathrm{Pb}$ dan As dalam pakan sapi menurut National Research Council (NRC) dan batas konsentasi logam $\mathrm{Pb}$ dan As yang disyaratkan dalam air sehingga layak untuk diminum menurut Permenkes tahun 1975 untuk $\mathrm{Pb}$ dan As dalam Pakan Sapi dan Air Minum (ppm) adalah Pb 30 ppm (pakan) dan 0,01 ppm (air), dan As 50 ppm (pakan) dan 0,05 ppm (air).

Batas toleransi ini merupakan kandungan logam $\mathrm{Pb}$ dan $\mathrm{As}$ dalam pakan yang aman bagi ternak sapi dan bagi manusia yang mengkonsumsi produk asal ternak sapi tersebut. Batas toleransi pada tiap hewan akan bervariasi karena kepekaan hewan terhadap toksisitas logam bergantung pada kondisi biologis hewan yang bersangkutan, yaitu umur, status kesehatan, bunting, menyusui, dan kondisi lingkungan (Darmono, 2001).

\section{Kadar Timbal (Pb)}

Pencemaran $\mathrm{Pb}$ berasal dari sumber alami maupun limbah hasil aktivitas manusia dengan jumlah yang terus meningkat, baik di lingkungan air, darat, maupun udara (Lu, 1995; Widowati et al., 2008). Akibat adanya pencemaran logam $\mathrm{Pb}$, kemungkinan pakan ternak tercemar oleh logam $\mathrm{Pb}$ sangat besar sehingga perlu diwaspadai karena logam $\mathrm{Pb}$ tersebut dapat mengganggu kesehatan ternak 
dan secara tidak langsung dapat mengganggu kesehatan manusia yang mengkonsumsi produk asal ternak tersebut.

\section{Pakan Hijauan Rumput dan Klobot} Jagung. Kadar logam $\mathrm{Pb}$ yang terdeteksi pada rumput lapangan berkisar antara 8,064 14,385 ppm dengan limit deteksi adalah 0,040 ppm. Kadar logam $\mathrm{Pb}$ pada rumput tertinggi berasal dari Gunung Bubut yaitu sebesar 14,358 ppm. Tingginya kadar logam $\mathrm{Pb}$ rumput lapangan asal Gunung Bubut disebabkan lokasi tempat tumbuhnya rumput berada dekat dengan jalan raya, yaitu sekitar 2-3 meter dari jalan raya. Berbeda dengan kadar logam $\mathrm{Pb}$ rumput lapangan asal Darmaga yang memiliki kadar logam $\mathrm{Pb}$ lebih rendah $(8,066 \mathrm{ppm})$, hal ini disebabkan jarak tempat tumbuhnya rumput lapangan dengan jalan raya lebih jauh (> $25 \mathrm{~m})$, selain itu di sekitar tempat tumbuhnya rumput banyak ditumbuhi oleh tumbuhan-tumbuhan besar. Keberadaan tumbuhan besar di sekitar rumput dapat menghalangi jatuhnya partikel-partikel $\mathrm{Pb}$ yang berasal dari asap yang dikeluarkan oleh kendaraan bermotor pada permukaan daun/rumput. Hasil pengukuran logam $\mathrm{Pb}$ pada rumput terdapat pada Tabel 2 .

Kadar logam $\mathrm{Pb}$ klobot jagung berkisar antara 7,633 - 8,626 ppm. Klobot jagung didapat dari limbah sayuran pasar, diantaranya Pasar Bogor dan Pasar Kemang, sedangkan jagung yang dikirim ke pasar dapat berasal dari beberapa wilayah seperti Ciawi dan Leuwiliang. Klobot jagung dapat tercemar logam $\mathrm{Pb}$ karena klobot jagung tersebut di dapat dari limbah sayuran pasar-pasar tradisional yang kondisinya dapat dikatakan kotor, selain itu klobot jagung yang dibuang diletakkan diatas aspal dan bercampur dengan sampah lain seperti kertas koran dan debu jalanan yang banyak mengandung logam $\mathrm{Pb}$, sehingga klobot-klobot jagung tersebut dapat tercemar logam $\mathrm{Pb}$.

Pencemaran logam $\mathrm{Pb}$ pada klobot jagung dapat terjadi sama seperti rumput, yaitu ketika rumput dan tanaman jagung sedang tumbuh atau belum dipanen. Pencemaran logam $\mathrm{Pb}$ pada kedua tanaman tersebut terjadi akibat tanah, air dan udara yang tercemar. Pencemaran $\mathrm{Pb}$ oleh tanah erat hubungannya dengan pencemaran udara dan air. Sumber pencemar utama logam $\mathrm{Pb}$ di udara berasal dari asap yang dikeluarkan oleh kendaraan bermotor, karena $\mathrm{Pb}$ biasa ditambahkan pada bensin sebagai zat anti letup. Rumput dan tanaman jagung dapat tercemar logam $\mathrm{Pb}$ melalui penyerapan akar dari tanah atau melalui stomata daun dari udara. Penyerapan pada daun terjadi karena

Tabel 2. Hasil Pengukuran Logam Pb dan As pada Rumput dan Klobot Jagung

\begin{tabular}{clclcc}
\hline \multirow{2}{*}{ No. } & \multirow{2}{*}{ Jenis Sampel } & \multirow{2}{*}{ Peternakan* } & \multicolumn{2}{c}{ Sumber Pakan } & \multicolumn{2}{c}{ Konsentrasi } \\
\cline { 4 - 6 } & & $\mathrm{R} 1$ & Darmaga & 8,064 & $\mathrm{As}$ \\
\hline 1 & Rumput lapangan & $\mathrm{R} 2$ & Yasmin & 11,708 & $\mathrm{Ttd}$ \\
2 & Rumput lapangan & $\mathrm{R} 3$ & Darmaga, Bubulak & 8,095 & $\mathrm{Ttd}$ \\
3 & Rumput lapangan & $\mathrm{C} 1$ & Cibalagung & 11,049 & $\mathrm{Ttd}$ \\
4 & Rumput lapangan & $\mathrm{C} 2$ & Cibalagung & 11,049 & $\mathrm{Ttd}$ \\
5 & Rumput lapangan & $\mathrm{C} 3$ & Gunung Bubut & 14,385 & $\mathrm{Ttd}$ \\
6 & Rumput lapangan & $\mathrm{K} 1$ & Pasar Kemang & 8,371 & $\mathrm{Ttd}$ \\
7 & Klobot jagung & $\mathrm{K} 2$ & Pasar Warung Jambu & 8,626 & $\mathrm{Ttd}$ \\
8 & Klobot jagung & $\mathrm{K} 3$ & Pasar Anyar & 8,321 & $\mathrm{Ttd}$ \\
9 & Klobot jagung & $\mathrm{C} 1$ & Pasar Kemang & 7,633 & $\mathrm{Ttd}$ \\
10 & Klobot jagung & $\mathrm{C} 2$ & Pasar Kemang & 7,633 & $\mathrm{Ttd}$ \\
11 & Klobot jagung & $\mathrm{C} 3$ & Pasar Bogor & 7,850 & $\mathrm{Ttd}$ \\
12 & Klobot jagung & & & &
\end{tabular}

\section{Keterangan :}

$\mathrm{R}=$ Peternakan dengan pakan rumput

$\mathrm{K} \quad$ = Peternakan dengan pakan klobot jagung

$\mathrm{C}=$ Peternakan dengan pakan rumput dan klobot jagung

ttd $=$ Tidak terdeteksi (dengan limit deteksi $\mathrm{Pb}=0,40 \mathrm{ppm}$ dan $\mathrm{As}=11 \mathrm{ppb}$ ) 
partikel $\mathrm{Pb}$ di udara masuk ke dalam daun melalui proses penyerapan pasif (Antari et al., 2002).

Jumlah logam $\mathrm{Pb}$ dalam tanah dapat semakin tinggi, karena partikel-partikel $\mathrm{Pb}$ dari asap yang dikeluarkan oleh kendaraan bermotor akan jatuh di atas permukan tanah sehingga dapat berakumulasi. Menurut Diapari et al. (2008), kandungan $\mathrm{Pb}$ tanah permukaan jauh lebih tinggi daripada kandungan $\mathrm{Pb}$ hijauan makanan ternak. Kadar $\mathrm{Pb}$ dalam tanah berkisar antara 2-200 ppm dengan kadar rata-rata 16 ppm, tetapi akibat kegiatan manusia terutama industri dan kendaraan bermotor yang menggunakan bahan bakar ber$\mathrm{Pb}$, kadar $\mathrm{Pb}$ di lapisan tanah permukaan dapat mencapai 1600-2400 ppm (Sustiawan, 1999). Tingginya kandungan $\mathrm{Pb}$ tanah disebabkan tanah sendiri sudah mengandung $\mathrm{Pb}$ dan jumlahnya terus bertambah akibat pencemaran yang terjadi, namun $\mathrm{Pb}$ yang tinggi dalam tanah permukaan tidak disertai dengan tingginya kandungan $\mathrm{Pb}$ hijauan pakan. Hal ini disebabkan $\mathrm{Pb}$ dalam tanah terdapat dalam kondisi kompleks yang tidak larut, sehingga tidak mudah diserap oleh tanaman pakan.

\section{Pakan Penguat Konsentrat, Ampas Tahu} dan Ampas Tempe. Kadar logam $\mathrm{Pb}$ konsentrat yang berasal dari koperasi sebesar 10,358 ppm (Tabel 3). Kadar logam $\mathrm{Pb}$ tersebut lebih tinggi dibandingkan pakan penguat lain seperti ampas tahu dan ampas tempe. Tingginya kadar logam $\mathrm{Pb}$ dalam konsentrat dapat disebabkan oleh bahan baku yang telah tercemar logam $\mathrm{Pb}$. Bahan baku konsentrat sapi perah asal KPS Bogor sebagian besar berupa limbah pengolahan hasil pertanian seperti dedak, onggok dan pollard, sehingga untuk mendapatkan konsentrat lebih mudah ketika musim panen tiba. Kualitas bahan baku konsentrat sangat bervariasi, baik dilihat dari nilai nutrisi maupun dari keberadaan residu (termasuk $\mathrm{Pb}$ ) didalamnya.

Tabel 3. Hasil Pengukuran Logam Pb dan As pada Konsentrat, Ampas Tahu dan Ampas Tempe

\begin{tabular}{clclcc}
\hline \multirow{2}{*}{ No. } & \multirow{2}{*}{ Jenis Sampel } & Peternakan* & Sumber Pakan & \multicolumn{2}{c}{ Konsentrasi } \\
\cline { 5 - 6 } 1 & Konsentrat & Komposit & KPS Bogor & 10,358 & $\mathrm{As}(\mathrm{ppm})$ \\
2 & Ampas tahu & $\mathrm{R} 1$ & Ciluar & 6,935 & $\mathrm{ttd}$ \\
3 & Ampas tahu & $\mathrm{R} 2$ & Tanjung Priok & $\mathrm{ttd}$ & $\mathrm{ttd}$ \\
4 & Ampas tahu & $\mathrm{R} 3$ & Tanjung Priuk & 8,260 & $\mathrm{ttd}$ \\
5 & Ampas tahu & $\mathrm{K} 1$ & Tanjung Priuk & $\mathrm{ttd}$ & $\mathrm{ttd}$ \\
6 & Ampas tahu & $\mathrm{K} 2$ & Cimanggu & 7,657 & $\mathrm{ttd}$ \\
7 & Ampas tahu & $\mathrm{K} 3$ & Tanjung Priok & 6,768 & $\mathrm{ttd}$ \\
8 & Ampas tahu & $\mathrm{C} 1$ & Tanjung Priok & 1,351 & $\mathrm{ttd}$ \\
9 & Ampas tahu & $\mathrm{C} 2$ & Tanjung Priok & 1,351 & $\mathrm{ttd}$ \\
10 & Ampas tahu & $\mathrm{C} 3$ & Cimanggu & $\mathrm{ttd}$ & $\mathrm{ttd}$ \\
11 & Ampas tempe & $\mathrm{R} 1$ & Kebon Pedes & 6,817 & $\mathrm{ttd}$ \\
12 & Ampas tempe & $\mathrm{R} 2$ & Tanjung Priok & 8,500 & $\mathrm{ttd}$ \\
13 & Ampas tempe & $\mathrm{R} 3$ & Tanjung Priok & 6,519 & $\mathrm{ttd}$ \\
14 & Ampas tempe & $\mathrm{K} 1$ & Tanjung Priok & 7,978 & $\mathrm{ttd}$ \\
15 & Ampas tempe & $\mathrm{K} 3$ & Tanjung Priok & 6,771 & $\mathrm{ttd}$ \\
16 & Ampas tempe & $\mathrm{C} 1$ & Tanjung Priok & 8,500 & $\mathrm{ttd}$ \\
17 & Ampas tempe & $\mathrm{C} 2$ & Tanjung Priok & 8,500 & $\mathrm{ttd}$ \\
18 & Ampas tempe & $\mathrm{C} 3$ & Cimanggu & 6,419 & $\mathrm{ttd}$ \\
\hline
\end{tabular}

Keterangan :

$\mathrm{R} \quad=$ Peternakan dengan pakan rumput

$\mathrm{K} \quad$ = Peternakan dengan pakan klobot jagung

$\mathrm{C} \quad=$ Peternakan dengan pakan rumput dan klobot jagung

$\mathrm{ttd}=$ Tidak terdeteksi (dengan limit deteksi $\mathrm{Pb}=0,40 \mathrm{ppm}$ dan $\mathrm{As}=11 \mathrm{ppb}$ ) 
Bahan baku konsentrat yang berasal dari limbah pengolahan hasil pertanian mempunyai resiko yang besar terhadap pencemaran logam $\mathrm{Pb}$ karena limbah-limbah tersebut biasanya tidak ditangani secara baik, terutama saat pengolahan dan penyimpanan. Hal ini merupakan penyebab konsentrat yang dihasilkan tercemar logam $\mathrm{Pb}$.

Kadar logam $\mathrm{Pb}$ ampas tahu yang diperoleh dari hasil sampingan pengolahan tahu berkisar antara tidak terdeteksi hingga $8,260 \mathrm{ppm}$, sedangkan untuk ampas tempe berkisar antara 6,419 ppm - 8,500 ppm. Umumnya ampas tahu dan ampas tempe tersebut berasal dari wilayah Tanjung Priok, Jakarta. Kadar logam $\mathrm{Pb}$ yang terdeteksi pada ampas tahu dan ampas tempe disebabkan penggunaan bahan baku yang tercemar dan kontaminasi yang terjadi selama proses pengolahan. Menurut Sarwono et al. (2003) ada beberapa sumber pencemaran dalam pengolahan tahu yaitu saat penggunaan air, proses pencetakan secara manual, pemakaian bahan tambahan makanan, penggunaan alat kerja, lingkungan sekitar, dan pekerja. Selain itu, pencemaran logam $\mathrm{Pb}$ pada ampas tahu dan ampas tempe dapat terjadi saat pendistribusian ke Kebon Pedes. Hal ini terjadi karena pendistribusian ampas tahu dan ampas tempe dilakukan menggunakan mobil pick-up terbuka dan melalui jalur padat kendaraan, terutama yang berasal dari Tanjung Priok.

Air Minum Ternak. Kadar logam $\mathrm{Pb}$ air minum dari seluruh sampel air yang dipergunakan asal Peternakan Sapi Perah Kelurahan Kebon Pedes tidak terdeteksi adanya logam $\mathrm{Pb}$ atau kurang dari 0,040 ppm. Sumber air minum ternak dan air minum penduduk memiliki sumber yang sama, yaitu air sumur. Air yang digunakan secara fisik tampak jernih dan tidak berbau. Hasil ini menunjukkan bahwa kadar logam $\mathrm{Pb}$ asal Kelurahan Kebon Pedes lebih rendah dari batas toleransi maksimum yang ditetapkan dalam Permenkes tahun 1975 yaitu 0,01 ppm. Menurut Effendi (2000), logam $\mathrm{Pb}$ pada perairan ditemukan dalam bentuk terlarut dan tersuspensi. Kelarutan $\mathrm{Pb}$ cukup rendah se- hingga kadar $\mathrm{Pb}$ di dalam air relatif rendah. Perairan tawar alami biasanya memiliki kadar $\mathrm{Pb}$ kurang dari $0,05 \mathrm{mg} / \mathrm{liter}$. Kadar dan toksisitas $\mathrm{Pb}$ dipengaruhi oleh kesadahan, $\mathrm{pH}$, alkalinitas, dan kadar oksigen. Timbal di perairan tawar membentuk senyawa kompleks yang memiliki sifat kelarutan rendah dengan beberapa anion seperti hidroksida dan sulfida.

\section{Kadar Arsen (As)}

Logam As merupakan unsur yang melimpah secara alami, termasuk golongan semilogam yang dapat mencemari tanah, air dan udara melalui proses erosi atau letusan gunung merapi (Widowati et al., 2008). Penggunaan logam As dalam dunia pertanian sebagai pestisida merupakan sumber utama kontaninsi As dalam tanah atau air tanah (Notodarmojo, 2005).

Pakan Hijauan Rumput dan Klobot Jagung. Kadar logam As pada rumput dan klobot jagung yang berasal dari peternakan yang menggunakan hijauan berupa rumput, klobot jagung dan campuran antara rumput dan klobot jagung menunjukkan hasil tidak terdeteksi atau kurang dari $11 \mathrm{ppb}$ (Tabel 2). Hasil ini menunjukkan kemungkinan bahwa rumput dan tanaman jagung tidak ditanam dan tumbuh pada lokasi yang tercemar logam As, serta tidak terjadinya pencemaran karena penggunaan pestisida yang mengandung As. Pencemaran juga tidak terjadi ketika transportasi dan selama penyimpanan setelah rumput dan tanaman jagung dipanen. Awalnya keberadaan logam As pada rumput dan klobot jagung dicurigai berasal dari penggunaan pestisida yang mengandung As. Pestisida semakin banyak digunakan oleh petani seiring dengan penerapan sistem intensifikasi pertanian. Penggunaan pestisida tersebut dalam pertanian berpotensi menimbulkan dampak negatif bagi lingkungan, yaitu terjadi pencemaran lingkungan (air, tanah, dan udara) serta menumpuknya pestisida dalam jaringan tubuh organisme melalui rantai makanan (bioakumulasi) (Djojosumarto, 2008). 
Pakan Penguat Konsentrat, Ampas Tahu dan Ampas Tempe. Kadar logam As konsentrat, ampas tahu dan ampas tempe dalam bahan-bahan tersebut tidak terdeteksi keberadaannya atau kurang dari $11 \mathrm{ppb}$ (Tabel 3). Awalnya keberadaan logam As dalam konsentrat, ampas tahu dan ampas tempe dicurigai berasal dari kemungkinan telah terjadinya pencemaran logam As pada bahanbahan tersebut. Pencemaran yang terjadi bisa berasal dari bahan baku dan bahan tambahan yang digunakan, peralatan kerja yang digunakan, kontaminasi dari pekerja, dan lingkungan sekitar. Pencemaran juga dapat terjadi selama penyimpanan dan transportasi.

Air Minum Ternak. Kadar logam As air minum dari seluruh sampel air yang dipergunakan asal Peternakan Sapi Perah Kelurahan Kebon Pedes tidak terdeteksi adanya logam As atau kurang dari $11 \mathrm{ppb}$ (Tabel 4). Kadar logam As ini lebih rendah dari batas toleransi maksimum yang ditetapkan, baik menurut WHO maupun Permenkes tahun 1975 yaitu 0,05 ppm. Menurut Effendi (2000), kadar logam As pada perairan tawar sekitar $0,01 \mathrm{mg} / \mathrm{liter}$ dan untuk keperluan air minum sebaiknya kadar logam As tidak melebihi $0,05 \mathrm{mg} / \mathrm{liter}$. Logam arsen di perairan alami membentuk senyawa arsenat $\left(\mathrm{AsO}_{4}{ }^{3-}\right)$ atau arsenit $\left(\mathrm{AsO}_{3}{ }^{3-}\right)$. Senyawa anaorganik arsen dapat diubah secara biologis menjadi senyawa argon arsen yang bersifat toksin. Sumber arsen di perairan adalah logam arsenide dan sulfida, misalnya niccolite dan arsenopylite. Selain itu, pelapukan batuan juga melepas arsen dalam bentuk oksida $\left(\mathrm{As}_{2} \mathrm{O}_{3}\right)$ dan senyawa sulfur (AsS) dan $\mathrm{As}_{2} \mathrm{~S}_{3}$ ).

\section{Logam Berat Timbal (Pb) dan Arsen (As) dalam Susu}

Susu merupakan bahan pangan asal ternak yang sangat penting karena mengandung nutrisi yang sangat dibutuhkan oleh manusia. Kualitas susu akan berkurang akibat keberadaan residu di dalam susu yang dapat membahayakan kesehatan manusia, diantaranya yaitu residu logam berat $\mathrm{Pb}$ dan $\mathrm{As}$.

\section{Kadar Timbal (Pb)}

Hasil pengukuran logam $\mathrm{Pb}$ dalam susu asal sapi perah Kelurahan Kebon Pedes yang menggunakan tiga jenis pakan yaitu rumput lapangan, klobot jagung serta campuran antara rumput lapangan dan klobot jagung tersebut tidak terdeteksi atau kurang dari $0,040 \mathrm{ppm}$ (Tabel 4).

Residu logam $\mathrm{Pb}$ dalam susu asal Kelurahan Kebon Pedes lebih rendah dari batas maksimum residu menurut SNI 013141-1998 yaitu 0,3 ppm. Logam $\mathrm{Pb}$ yang masuk ke dalam tubuh sapi karena mengkonsumsi pakan yang mengandung logam $\mathrm{Pb}$ tidak disertai dengan terdeteksinya logam tersebut dalam susu yang dihasilkan. Hal ini mungkin disebabkan logam $\mathrm{Pb}$ yang didistribusikan dan diekskresikan melalui susu jumlahnya sangat kecil, akan tetapi pendistribusiannya lebih banyak pada jaringan atau organ-organ lain dalam tubuh ternak seperti pada hati, ginjal, dan daging jumlahnya lebih tinggi dibandingkan logam $\mathrm{Pb}$ yang terdeteksi dalan susu. Logam $\mathrm{Pb}$ yang termakan oleh sapi terutama disimpan dalam hati dan ginjal, dan dalam kedua organ inilah logam $\mathrm{Pb}$ akan terakumulasi (Parakkasi, 1998).

\section{Kadar Arsen (As)}

Residu logam As dalam susu asal Kelurahan Kebon Pedes yang menggunakan tiga jenis pakan berbeda yaitu rumput lapangan, klobot jagung serta campuran antara rumput lapangan dan klobot jagung menunjukkan hasil tidak terdeteksi atau kurang dari $11 \mathrm{ppb}$ (Tabel 4). Residu logam As dalam susu tersebut lebih rendah dari batas maksimum residu menurut SNI 01-3141-1998 yaitu $0,5 \mathrm{ppm}$. Keberadaan residu logam As dalam susu awalnya dicurigai karena sapi mengkonsumsi pakan dan air minum yang tercemar logam As, sehingga logam As dapat masuk ke dalam tubuh sapi, setelah masuk melalui saluran pencernaan di dalam tubuh sebagian diekresikan melalui air susu. Menurut Widowati et al. (2008) pencemaran logam As dapat terjadi karena logam As secara luas 
Tabel 5. Hasil Pengukuran Logam Berat ( $\mathrm{Pb}$ dan $\mathrm{As}$ ) pada Susu Segar

\begin{tabular}{cccc}
\hline No. & Peternakan & $\mathrm{Pb}$ & Konsentrasi \\
& & $\mathrm{As}$ \\
\hline 1 & $\mathrm{R} 1(1 / \mathrm{X})$ & $\mathrm{Ttd}$ & $\mathrm{Ttd}$ \\
2 & $\mathrm{R} 2(4 / \mathrm{X})$ & $\mathrm{Ttd}$ & $\mathrm{Ttd}$ \\
3 & $\mathrm{R} 3(6 / \mathrm{X})$ & $\mathrm{ttd}$ & $\mathrm{Ttd}$ \\
4 & $\mathrm{~K} 1(3 / \mathrm{X})$ & $\mathrm{ttd}$ & $\mathrm{Ttd}$ \\
5 & $\mathrm{~K} 2(1 / \mathrm{III})$ & $\mathrm{ttd}$ & $\mathrm{Ttd}$ \\
6 & $\mathrm{~K} 3(6 / \mathrm{IX})$ & $\mathrm{ttd}$ & $\mathrm{Ttd}$ \\
7 & $\mathrm{C} 1(4 / \mathrm{X})$ & $\mathrm{ttd}$ & $\mathrm{Ttd}$ \\
8 & $\mathrm{C} 2(4 / \mathrm{X})$ & $\mathrm{ttd}$ & $\mathrm{Ttd}$ \\
9 & $\mathrm{C} 3(6 / \mathrm{IX})$ & $\mathrm{ttd}$ & $\mathrm{Ttd}$ \\
\hline
\end{tabular}

Keterangan :

$\mathrm{R} *=$ Peternakan dengan pakan rumput

$\mathrm{K} *$ = Peternakan dengan klobot jagung

$\mathrm{C}^{*}=$ Peternakan dengan pakan rumput dan klobot jagung

ttd $=\quad$ Tidak terdeteksi (dengan limit deteksi $\mathrm{Pb} 0,40 \mathrm{ppm}$ dan $\mathrm{As}=11 \mathrm{ppb}$ )

digunakan dalam bidang pertanian, antara lain sebagai pestisida dan soil sterilants sehingga tanah pertanian dapat tercemar As dalam konsentrasi tinggi, namun karena penggunaan logam As dalam pestisida sudah dilarang sehingga kemungkinan tersebut menjadi sangat kecil. Logam As yang masuk ke dalam tubuh akan ditransportasikan menuju berbagai organ dan jaringan. Logam As dalam tubuh terutama diakumulasikan di kulit, kuku, rambut, tulang dan otot.

\section{KESIMPULAN}

Susu yang berasal dari peternakan sapi perah di Kelurahan Kebon Pedes yang mendapat pakan hijauan berbeda, yaitu: rumput lapangan, klobot jagung asal limbah sayuran pasar dan campuran antara rumput lapangan dan klobot jagung asal limbah sayuran pasar tidak terdeteksi adanya logam $\mathrm{Pb}$ dan As. Nilai ini masih masuk batas maksimum residu menurut SNI 01-3141-1998 yaitu 0,3 ppm dan 0,5 ppm.

\section{DAFTAR PUSTAKA}

Antari A. A. R. J. dan K. Sundra. 2002. Kandungan Timah Hitam (Plumbum) pada Tanaman Peneduh Jalan di Kota Denpasar. Fakultas Matemetika dan Ilmu Pengetahuan Alam. Universitas
Udayana, Bali. http://ejournal. unud.ac.id/ abstrak/4.pdf [20 Maret 2009].

Caggiano R., Sabia S., D’Emilio M., Macchiato M., Anastasio A., Ragosta M., and Paino S., (2005), Metallevels in fodder, milk, dairy products, and tissues sampled in ovine farms of Southern Italy, Environmental Research, 99, 4857

Darmano. 1995. Logam dalam Sistem Biologi Makhluk Hidup. Universitas Indonesia Press, Jakarta.

Darmono. 2001. Lingkungan Hidup dan Pencemaran: Hubungannya dengan Taksikologi Senyawa Logam. Universitas Indonesia Press, Jakarta.

Diapari, D., H. M. H. Bintoro, J. Jachja, K. A. Notodiputro dan M. S. Saeni. 2008. Kejadian hujan asam di Kabupaten Bogor dan retensi timbal pada domba lokal yang diberi ransum berkadar timbal tinggi. Jurnal Ilmu Pengetahun dan Teknologi Peternakan. 31 (3): 203211.

Djojosumarto, P. 2008. Pestisida dan Aplikasinya. Agromedia Pustaka, Jakarta.

Effendi, H. 2000. Telaah Kualitas Air bagi Pengelolaan Sumber Daya dan 
Lingkungan Perairan. Kanisius, Yogyakarta.

Kinsara, A. A. and S. M. Farid. 2004. Concentration of trace elements in human and animal milk in Jeddah,Saudi Arabia. Medical Journal of Islamic World Academy of Sciences 16:4, 181188 www.medicaljournalias.org/.../KinsaraXTDIR

Lu, F. C. 1995. Toksikologi Dasar: Asas, Organ Sasaran, dan Penilaian Resiko. Terjemahan: Edi Nugroho. Universitas Indonesia Press, Jakarta.

Notodarmojo, S. 2005. Pencemaran Air dan Air Tanah. Penerbit ITB, Bandung.

Parakkasi, A. 1998. Ilmu Nutrisi dan Makanan Ternak Ruminan. Universitas Indonesia Prees, Jakarta.

Saeni, M. S. 1997. Penentuan Tingkat Pencemaran Logam Berat dengan Analisis Rambut. Orasi Ilmiah. Fakultas Matematika dan Pengetahuan Alam. Institut Pertanian Bogor, Bogor.

Samples, D dan J. McCutcheon. 2003.
Grazing Corn Residue. http//www. ohioline.osu.edu [20 Mei 2008].

Sarwono, B. dan Y. P. Saragih. 2003. Membuat Aneka Tahu. Penebar Swadaya, Jakarta.

Siregar, S. B. 1992. Sapi Perah: Jenis Teknik Pemeliharaan dan Analisis Usaha. Penebar Swadaya, Jakarta.

Sustiawan, B. 1999. Pengaruh logam berat timbal $(\mathrm{Pb})$ terhadap pertumbuhan serta kondisi organ hati dan ginjaltikus percobaan. Tesis. Progaram Pascasarjana. Institut Pertanian Bogor, Bogor.

Widowati, W., A. Sastiono, R. J. Rumampuk. 2008. Efek Toksik Logam Pencegahan dan Penanggulangan Pencemaran. Penerbit Andi, Yogyakarta.

Zheng N., Wang Q., Zhang X., Zheng D., Zhang Z., Zhang S., (2007), Population health risk due to dietary intake of heavy metals in the industrial area of Huludao city, China, Science of the Total Environment, 387, 96-104. 